\title{
Investigations of injector deposits in modern diesel engines
}

\author{
Traces of some metallic elements that may contaminate diesel fuel are a very significant factor initiating and accelerat- \\ ing the formation of deposits in diesel injection systems. Such deposits disturb proper operation of modern high-pressure \\ injection systems, which has an adverse effect on the engine performance and operating parameters. The paper discusses \\ the results of engine tests related to the influence of traces of zinc on the deterioration of the operating parameters of \\ injection systems manifesting itself in decreased engine power.
}

Key words: fuel injector deposits, traces of metallic elements in the fuel, influence of deposits on injector operation

\section{Badanie osadów wtryskiwaczy nowoczesnych silników z zapłonem samoczynnym}

\begin{abstract}
Śladowe ilości niektórych pierwiastków metalicznych, mogących stanowić zanieczyszczenia oleju napędowego, sq̨ ważnym czynnikiem inicjujacym i przyspieszającym formowanie się osadów zanieczyszczajacych wtryskiwacze uktadów paliwowych silników z zapłonem samoczynnym. Osady takie powoduja zaburzenia w pracy nowoczesnych, wysokociśnieniowych układów wtrysku paliwa, a to niekorzystnie oddziałuje zarówno na osiagi silników, jak i ich inne walory użytkowo-eksploatacyjne. W pracy omówiono wyniki silnikowych badań wpływu śladowych ilości cynku zawartego woleju napędowym na pogorszenie parametrów pracy układu wtrysku paliwa i spowodowane tym zmniejszenie mocy silnika.

Słowa kluczowe: osady wtryskiwaczy paliwa, śladowe pierwiastki metaliczne $w$ paliwie, oddziaływanie osadów na funkcjonowanie wtryskiwaczy
\end{abstract}

\section{Introduction}

A dynamic design and constructional development of spark ignition and diesel engines has led to their significant advancement in terms of the injection and combustion control processes. A consequent implementation of increasingly stringent exhaust emissions legislation $\left(\mathrm{CO}, \mathrm{HC}\right.$ and $\left.\mathrm{NO}_{\mathrm{v}}\right)$, particularly related to the emission of particle mass (PM) and particle number $(\mathrm{PN})$, forced the engineers to apply more complex aftertreatment systems such as DPF (Diesel Particulate Filter), SCR (Selective Catalytic Reduction) in diesel engines and TWC (three way catalytic converters) for spark ignition engines.

A consequent reduction of the emission of $\mathrm{CO}_{2}$ from piston engines is also growing in importance. Downsizing is the answer to the problem. Downsizing in combustion engines consists in the reduction of the engine displacement (reduction of the number of cylinders or their volume), i.e. the engine weight, which results in better mechanical efficiency (reduction of friction in the mating pairs). At the same time, the engine performance is maintained or even improved while the unit fuel consumption $\left(\mathrm{CO}_{2}\right)$ decreases owing to the application of direct fuel injection or supercharging/turbocharging.

The result of the above is that the design of spark ignition and diesel engines becomes increasingly convergent while it becomes more and more sophisticated (complex engine aftertreatment) setting the bar high for the engine fuels and lubricants. These engines are particularly demanding in terms of fuel additives. Additives are important for the improvement and stabilization of the oil physicochemical and operating properties. An example of an important oil

\section{Wstęp}

Dynamicznie postępujący rozwój konstrukcyjny i technologiczny silników ZI (z zapłonem iskrowym) i ZS (z zapłonem samoczynnym) doprowadził do ich znacznego udoskonalenia, zwłaszcza w zakresie kontrolowania i sterowania procesami wtrysku paliwa oraz spalania. Jednak systematyczne wprowadzanie coraz ostrzejszych przepisów w zakresie zmniejszania emisji $\mathrm{CO}, \mathrm{HC}$ i $\mathrm{NO}_{\mathrm{x}}$, a w szczególności masowej (PM), a następnie liczbowej (PN) emisji cząstek stałych wymusiły na konstruktorach silników ZS stosowanie także coraz bardziej złożonych układów i rozwiązań pozasilnikowych, w tym tzw. następczej obróbki spalin, w skład których wchodzą między innymi filtry cząstek stałych DPF (Diesel Particulate Filter), układy redukcji katalitycznej SCR (Selective Catalytic Reduction) itd., a w odniesieniu do silników ZI - trójfunkcyjne układy katalityczne.

Obecnie również duże znaczenie ma konieczność sukcesywnego zmniejszania emisji $\mathrm{CO}_{2}$ przez zmniejszenie jednostkowego zużycia paliwa tłokowych silników spalinowych. Rozwiązaniem okazało się wprowadzenie tzw. downsizingu silników. Ten kierunek rozwoju silników polega na ich zmniejszaniu przez ograniczanie pojemności skokowej (zmniejszanie liczby cylindrów lub pojemności cylindrów), a tym samym masy silników i poprawie ich sprawności mechanicznej (obniżanie oporów tarcia między współpracującymi częściami). Równocześnie za pomocą różnych środków technicznych, a przede wszystkim bezpośredniego wtrysku paliwa i doładowania (sprężarką mechaniczną lub turbodoładowania), zachowuje się, a czasami nawet poprawia osiągi silników przy zmniejszeniu jednostkowego zużycia paliwa $\left(\mathrm{CO}_{2}\right)$. 
additive under strict control is detergents. They are used for optimum spark ignition and diesel engine performance [1-8]. Detergent additives are responsible for keeping the intake system (fighting deposits on the intake valves), fuel injection system (fighting internal and external deposits on the injector components) and combustion chamber in good conditions.

Figure 1 shows the influence of different (currently applied and future) technologies and design solutions for piston engines on the formation of deposits hazardous to engine components. This depicts the ever-growing and varied requirements that the fuel detergent additives will have to meet. These additives will be directly responsible for proper operation throughout the engine life cycle.

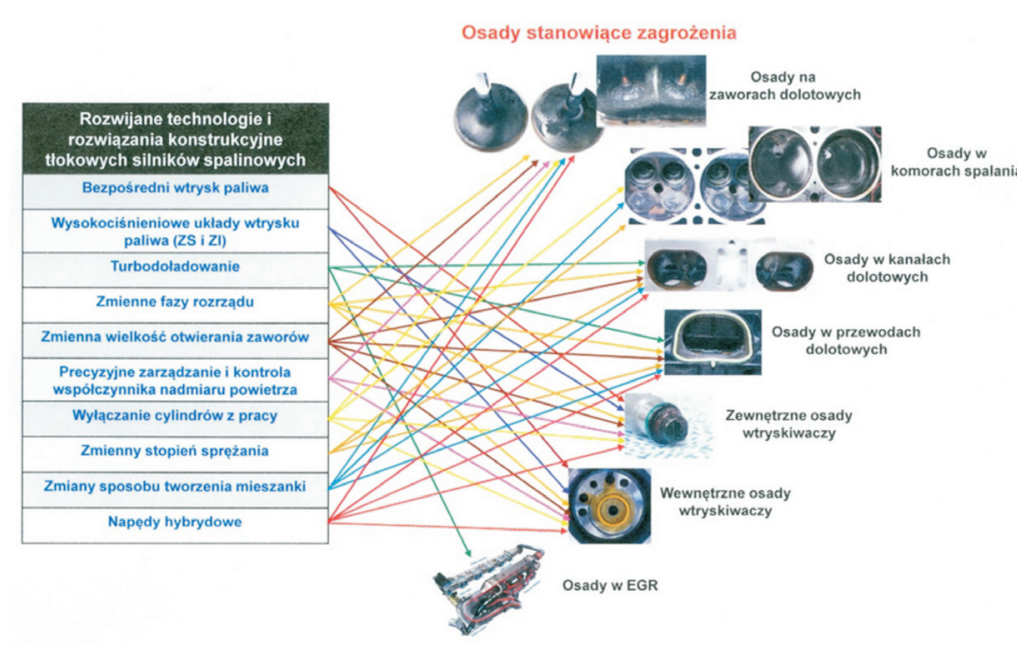

Fig. 1. The influence of various technologies and design solutions of piston engines on the formation of deposits hazardous to all engine components

Rys. 1. Wplyw różnych technologii i rozwiązań konstrukcyjnych tłokowych silników spalinowych na tworzenie osadów stanowiacych zagrożenia dla poprawnego funkcjonowania różnych podzespotów silnika

Direct fuel injection entailing the application of highpressure injectors operating under aggressive chemical environment of the combustion chambers exposed to high temperatures will be a serious challenge for the detergent additives that counteract the formation of injector external (coking) and internal deposits. This is particularly the case for diesel engines whose injection pressures are approximately ten times higher than in direct injected spark ignition engines. Consequently, the precision of the injector workmanship and fitting is much higher and the tendency to form deposits, particularly if lubricants containing bio-components or bio fuels are applied is even greater than in spark ignition engines. The threat resulting from the formation of external (coking) deposits on the injectors of indirect injected diesel had already been observed in the 1990's of the last century. The problems related to this type of deposits have become more serious ever since high-pressure injection systems along with low-sulfur diesel fuels became popular. The advancing changes of the technology of fuel production contributed to the appearance of more factors facilitating the formation of such deposits $[4,7,8]$. Moreover, several
W rezultacie konstrukcje silników ZI i ZS coraz bardziej zbliżają się do siebie, a równocześnie są coraz bardziej skomplikowane, rozbudowane o różne układy zewnętrzne i stawiają coraz wyższe wymagania zarówno paliwom, jak i smarowym olejom silnikowym. Szczególne wymagania dotyczą dodatków do paliw, stanowiących zazwyczaj składniki pakietu uszlachetniającego paliwa. Mają one coraz większe, wielorakie znaczenie zarówno w zakresie poprawy, jak i stabilizacji ich właściwości fizykochemicznych, a także użytkowo-eksploatacyjnych. Jednak szczególnie duże wymagania stawia się dodatkom detergentowym, dla optymalnego utrzymania osiągów silników zarówno ZI, jak i ZS w czasie eksploatacji [1-8]. Obecnie mają one za zadanie utrzymanie czystości układu dolotowego (przeciwdziałanie tworzeniu osadów na zaworach dolotowych), układu wtrysku paliwa (przeciwdziałanie tworzeniu wewnętrznych i zewnętrznych osadów na elementach wtryskiwaczy) oraz komór spalania.

$\mathrm{Na}$ rysunku 1 przedstawiono wpływ różnych, obecnie już stosowanych oraz przyszłych technologii i rozwiązań konstrukcyjnych tłokowych silników spalinowych na tworzenie osadów stanowiących zagrożenia dla poprawnego funkcjonowania różnych podzespołów silnika. Obrazuje to coraz szersze, a zarazem zróżnicowane wymagania, jakie będą stawiane dodatkom detergentowym do paliw, od których w coraz większym stopniu będzie uzależnione niezawodne, a jednocześnie optymalne działanie silnika w czasie całego okresu jego eksploatacji.

Bezpośredni wtrysk paliwa, wiążący się z koniecznością stosowania wysokociśnieniowych wtryskiwaczy pracujących w agresywnym środowisku chemicznym komór spalania i narażonych na wysokie temperatury, będzie stanowił duże wyzwanie dla dodatków detergentowych przeciwdziałających powstawaniu osadów zewnętrznych (koksowych) i wewnętrznych wtryskiwaczy. Dotyczy to szczególnie silników ZS, w których ciśnienia wtrysku paliwa są około dziesięciokrotnie wyższe aniżeli w silnikach ZI z bezpośrednim wtryskiem paliwa. W konsekwencji precyzja wykonania i montażu wtryskiwaczy jest jeszcze większa, a tendencje do tworzenia osadów zwłaszcza dla olejów napędowych zawierających biokomponenty lub biopaliw są jeszcze większe niż w układach silników ZI. Zagrożenia wynikające z tworzenia osadów zewnętrznych (koksowych) na wtryskiwaczach silników ZS z wtryskiem pośrednim stwierdzono już w latach dziewięćdziesiątych ubiegłego wieku. Problemy związane z tego typu osadami pogłębiły się po wprowadzeniu do stosowania i rozpowszechnieniu układów wysokociśnieniowego wtrysku paliwa w połączeniu z niskosiarkowymi olejami napędowymi. Postępujące zmiany technologii produkcji paliw przyczyniały się do powstawania kolejnych czynników sprzyjających powstawaniu takich osadów $[4,7,8]$. Dodatkowo, kilka lat temu, potwierdzono duże 


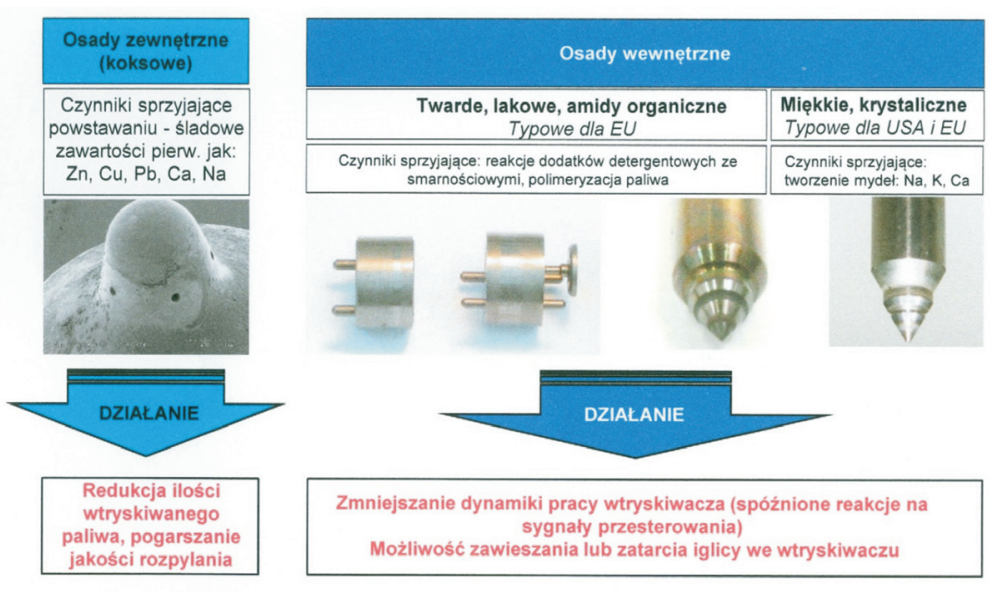

Fig. 2. Types of deposits formed inside and outside of the injectors in HPCR injection systems, factors facilitating their formation and impact on engine operation

Rys. 2. Typy osadów tworzonych na i we wtryskiwaczach ukladów HPCR, czynniki sprzyjajace ich powstawaniu i oddziatywanie na funkcjonowanie silnika

years ago a serious threat for proper operation of the HPCR systems (High Pressure Common Rail) has been confirmed resulting from the formation of internal deposits on the working components such as injectors or high-pressure pumps. The performed chemical analyses have shown that these deposits have different composition and morphology than the external coking deposits in the channels and outlet nozzles of the injectors. It has also been observed that the formation of this new group of deposits referred to as IDID (Internal Diesel Injector Deposit) and the conditions facilitating their growth are entirely different than those of the external coking deposits [2, 4, 6] - Fig. 2.

\section{Fuel injector deposit formation}

As far as external deposits (most often coking deposits) in HPCR (High Pressure Common Rail) systems are concerned, the greatest threat for the injector operation are the deposits forming in the injector channels and around the injector outlet holes - Fig. 3. In the initial phase of deposit formation they lead to a distortion of the fuel spray and change of its penetration, which has an adverse effect on the fuel atomization and mixing with air in the combustion chambers. The described fuel spray distortion may also lead to rinsing of the combustion chamber walls with fuel, which leads to incomplete combustion and higher exhaust emissions due to inadequate fuel evaporation. The deposits formed inside the injector channels gradually increase the hydraulic flow loss which results in uncontrolled quantitative and qualitative changes of the fuel injection into the combustion chamber, the consequence of which is engine reduced performance (e.g. reduced maximum power) - Fig. 3 .

The formation of deposits is facilitated by the slightly conical shape of the injector channels along with the rounded edges at the inlet (hydroerosion processing to improve the flow efficiency). The rounded edges at the inlet to the injector channels reduce cavitation. Cavitation influences the continuity of the fuel spray zagrożenia dla poprawnej pracy układów typu HPCR (High Pressure Common Rail), powodowane powstawaniem osadów wewnętrznych na elementach roboczych, zwłaszcza wtryskiwaczy paliwa, ale także pomp wysokiego ciśnienia. Przeprowadzone analizy chemiczne wykazały, że osady te mają odmienny skład i morfologię od dotychczas badanych, zewnętrznych osadów koksowych w kanalikach i wokół otworków wylotowych rozpylaczy. Równocześnie stwierdzono też, że czynniki powodujące powstawanie tej nowej grupy osadów, nazwanych osadami wewnętrznymi układów wtryskowych silników ZS (IDID - Internal Diesel Injector Deposit), i warunki sprzyjające ich przyrostowi są zupełnie inne niż dla zewnętrznych osadów koksowych $[2,4,6]-$ rys. 2 .

\section{Tworzenie osadów wtryskiwaczy paliwa}

W odniesieniu do zewnętrznych osadów (najczęściej koksowych) układów HPCR (High Pressure Common Rail) największe zagrożenie dla poprawności funkcjonowania wtryskiwaczy stanowią osady formujące się w kanalikach oraz wokół i na obrzeżach otworków wylotowych paliwa-rys. 3. W początkowej fazie tworzenia powodują one zniekształcenie strugi rozpylanego paliwa oraz zmianę jej zasięgu, co niekorzystnie wpływa na procesy rozdrobnienia i mieszania paliwa z powietrzem w komorach spalania silnika. Opisane zniekształcenia strug wtryskiwanego paliwa mogą też prowadzić do omywania ścianek komór spalania ciekłym paliwem, a to, na skutek niepełnego odparowania paliwa w ładunku powietrza, prowadzi do niezupełnego spalania i zwiększenia emisji składników szkodliwych do atmosfery. Tworzone wewnątrz kanalików osady stopniowo zwiększają straty przepływu hydraulicznego i powodują
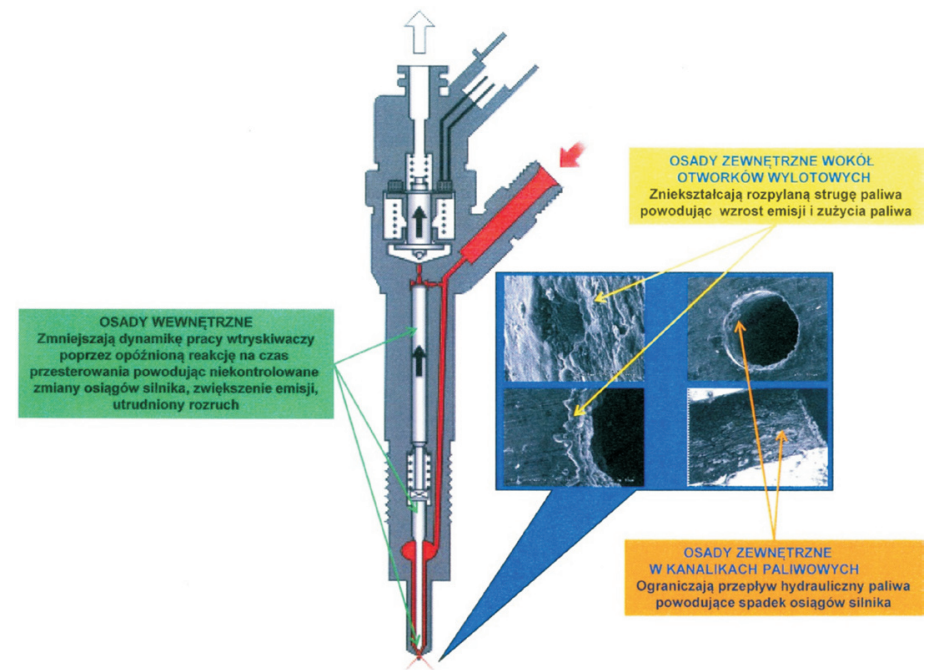

Fig. 3. Areas of occurrence of various types of internal and external deposits on the fuel injectors of high-pressure injection systems

Rys. 3. Obszary występowania różnych typów osadów we wtryskiwaczu układu wysokociśnieniowego wtrysku paliwa 
outflow but at the same time facilitates self-cleaning of the channels [3, 12-17].

High precision of HPCR injector workmanship (outlet holes diameter below $0.1 \mathrm{~mm}$ ), high injection pressure (220-250 MPa), direct influence of the combustion environment and high temperatures heating the nozzles up to $350{ }^{\circ} \mathrm{C}$ may even lead to a gradual occlusion and eventual blocking of the outlet when the engine remains inoperative for days - Fig. 4.

Extended chemical analyses of the deposits originating in the injection nozzles (around the fuel outlet holes) of HPCR injection systems have been carried out and published by Venkataraman and Eser [19]. The analyses have confirmed the presence of alkyl hydroxides, aldehydes, ketones, alcohols, ethers and acids, each of which may have formed following degradation in free radical thermo-oxidation processes of diesel fuel. In the conclusions the authors stated that
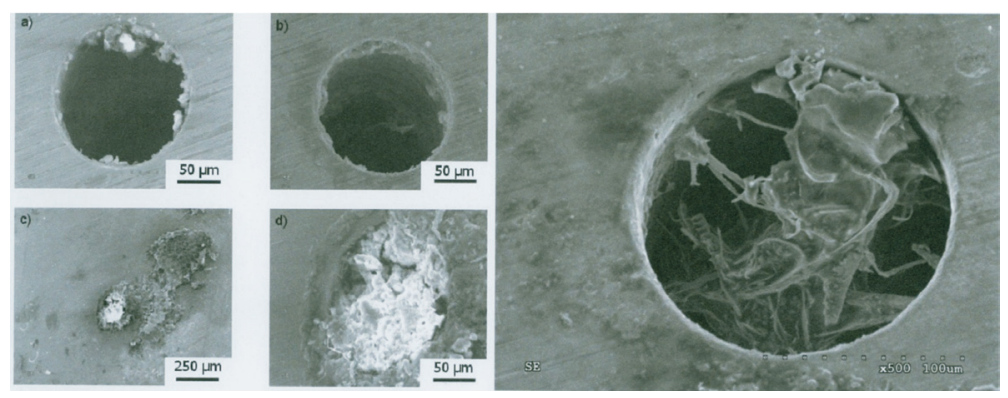

Fig. 4. View of the coking deposits formed around the edges and inside of the fuel spray holes in HPCR injection systems

Rys. 4. Osady koksowe utworzone na obrzeżach $i$ wewnatrz otworków wylotowych wtryskiwaczy uktadu HPCR

external coking deposits on the injectors had been formed as a result of thermo-oxidation processes occurring under aggressive conditions leading to the formation of alcoxylic and alkylo-peroxide structures transformed into cycloalkanes that may become aromatic following dehydrogenation. These processes lead to the formation of final deposits containing polycondensed aromatic hydrocarbons built in the structures of carbon deposits to a different extent.

Lepperhoff and Houben [20] have explained the physical mechanism of formation and increment of coking deposits along with the processes removing these deposits. The processes of deposit formation and increment begin as a result of temperature difference between the colder surfaces of the components (injectors) and gases and fluids of higher temperatures. As a result of this temperature gradient, the molecules forming the deposits move towards metal parts of the surfaces in the combustion region. The process of deposit formation is initiated by condensation and adsorption of gaseous chemical compounds on cold surfaces of metal walls. Further increment of the deposits is influenced by adhesion, impact and adsorption of the molecules. The adsorption of the gaseous compounds and the chemical reactions such as pyrolysis, dehydration and polymerization lead to an increased density of the deposits. The removal of niekontrolowane zmiany ilości i jakości paliwa wtryskiwanego do komór spalania silnika, co prowadzi do spadku jego osiągów (np. mocy maksymalnej) - rys. 3.

Powstawaniu osadów sprzyja dodatkowo stosowanie lekko stożkowych kanalików wtrysku paliwa wraz z zaokrąglonymi, przy wykorzystaniu obróbki hydroerozyjnej, krawędziami na wlocie w celu poprawy sprawności wypływu paliwa. Zaokrąglone krawędzie na wlocie kanalików ograniczają zjawiska kawitacji niekorzystnie wpływające na zaburzenia ciągłości wypływu strugi paliwa, ale równocześnie sprzyjające procesowi samooczyszczania kanalików $[3,12-17]$.

Duża precyzja wykonania wtryskiwaczy układów HPCR, a przy tym średnica otworków wylotowych paliwa często poniżej 0,1 mm, wysokie ciśnienia wtrysku paliwa (220-250 $\mathrm{MPa}$ ), a także bezpośrednie oddziaływanie środowiska procesów spalania oraz bardzo wysokie temperatury, do których mogą nagrzewać się końcówki wtryskiwaczy (dochodzące do około $350^{\circ} \mathrm{C}$ ) mogą doprowadzić nawet do stopniowego ,zarastania” i całkowitego zablokowania otworka paliwa przez osady, podczas co najmniej kilkudziesięciogodzinnego unieruchomienia silnika - rys. 4.

Szerokie analizy chemiczne osadów pochodzących z końcówek wtryskiwaczy (wokół otworków wylotowych paliwa) układu wtrysku paliwa typu HPCR zostały przeprowadzone i opublikowane przez Venkataramana i Esera [19]. Analizy wykazały obecność wodorotlenków alkilowych, aldehydów, ketonów, alkoholi, eterów i kwasów, z których każdy mógł powstać na skutek degradacji w wolnorodnikowych procesach termooksydacji oleju napędowego. W podsumowaniu autorzy stwierdzili, że zewnętrzne osady koksowe wtryskiwaczy zostały uformowane w wyniku procesów termooksydacji, przebiegających w ostrych warunkach, które doprowadziły do utworzenia struktur alkoksylowych i alkilo nadtlenkowych, przekształconych następnie w cykloalkany mogące aromatyzować w wyniku dehydrogenacji. Procesy te prowadzą do utworzenia finalnych osadów zawierających polikondensowane węglowodory aromatyczne w różnym stopniu wbudowane w struktury osadów węglowych.

Z kolei Lepperhoff i Houben [20] wyjaśnili fizyczny mechanizm powstawania i przyrostu osadów koksowych oraz procesy, w wyniku których osady te są usuwane. Procesy powstawania i przyrostu osadów rozpoczynają się na skutek różnicy temperatury pomiędzy chłodniejszymi powierzchniami elementów, np. wtryskiwaczy i gazami oraz płynami o wyższych temperaturach. W wyniku tego gradientu temperatury, cząsteczki tworzące osady przemieszczane są w kierunku metalowych powierzchni elementów w obszarze spalania. Proces formowania osadów jest inicjowany przez kondensację i adsorpcję gazowych związków chemicznych na chłodnych powierzchniach metalowych ścianek. Na dalszy przyrost osadów ma wpływ przywieranie, wbijanie się i adsorpcja cząstek. Adsorpcja gazowych związków, a także reakcje chemiczne, jak piroliza, dehydratacja i polimeryza- 
these deposits is facilitated by a variety of physical processes such as degradation of organic compounds in the deposits through oxidation processes or reduction of the gas fraction dissolved in the deposit layer through evaporation and desorption. Other mechanisms that remove the deposits are their abrasion and detachment resulting from aerodynamic forces of the gases acting on the deposits as well as temperature changes. The balance between the formation of the deposits on the injector and their subsequent removal is the result of the balance among many complex physicochemical processes.

Compounds containing oxygen, nitrogen, sulfur and traces of contaminant metals $(\mathrm{Zn}, \mathrm{Cu}, \mathrm{Ca}, \mathrm{Na}$ and $\mathrm{Mg}$ ) in the fuel are vital for the formation of the deposit precursors. It is assumed that the traces of these metals in the fuel may promote the formation of external deposits on the injectors through catalytic influence accelerating the fuel degradation [21]. Metallic catalysts usually accelerate the processes of deposits initiation and formation by the decomposition of hydrocarbons, while the thermal decomposition of fuel leads to the formation of carbon deposits by polymerization. A factor that intensifies the processes may be even small amounts of biocomponents contained in the fuel. Polarity of the components forming the precursors of deposits and their interaction with the metal surfaces on which the deposits form is also vital for the formation of deposits [2, 4, 6, 12]. The more probable, or, at least possible mechanism is assuming the deposition of oxides of a metallic element (e.g. $\mathrm{Zn}$ ) in the form of oxides inside the fuel channels of the injector $[22,23]$. These metalorganic deposits are a separate type of chemical deposits that were not perceived as bad for the operation of injection systems prior to the introduction of high-pressure injection systems. Figure 5 [12] shows the influence of the traces of various metals in the B10 fuel on the formation of metalorganic deposits inside the fuel channels of the HPCR injector. As we can observe, the greatest deposits in the channels were formed as a result of catalytic influence of $\mathrm{Zn}$ and $\mathrm{Cu}$ contained in the B10 fuel.

Similar conclusions related to the catalytic influence of metallic traces on the process of aging of diesel fuels containing 10\% $(\mathrm{V} / \mathrm{V})$ FAME and formation of deposits on the fuel channels of HPCR injectors have been drawn by Iida [12]. The said conclusions put the metallic traces contaminating the fuels and posing

cja, prowadzą do wzrostu gęstości osadów. Na usuwanie osadów natomiast mają wpływ różne procesy fizyczne, jak degradacja związków organicznych w osadach przez procesy utleniania czy też redukcja frakcji gazowej rozpuszczonej w powłoce osadów przez odparowanie i desorpcje. Innymi mechanizmami powodującymi usuwanie osadów są ścieranie i odrywanie osadów przez oddziaływanie sił aerodynamicznych, powodowanych silnym oddziaływaniem gazów omywających osady, a także przez zmiany temperatury. W rezultacie wyważenie pomiędzy tworzeniem i usuwaniem osadów z powierzchni wtryskiwacza jest wynikiem równowagi pomiędzy wieloma złożonymi procesami fizyczno-chemicznymi mającymi wpływ na osady.

Dla formowania prekursorów osadów duże znaczenie mają związki zawierające tlen, azot oraz siarkę, a także znajdujące się w paliwach, najczęściej w śladowych ilościach, metale stanowiące zanieczyszczenia (w szczególności Zn, $\mathrm{Cu}, \mathrm{Ca}, \mathrm{Na}$ i Mg). Zakłada się, że te śladowe ilości metali zawartych w paliwach mogą promować formowanie osadów zewnętrznych wtryskiwaczy przez działanie katalityczne, przyspieszające degradację paliwa [21]. Metaliczne katalizatory zazwyczaj przyspieszają procesy inicjowania

a)

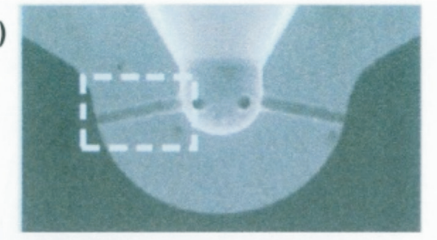

b)

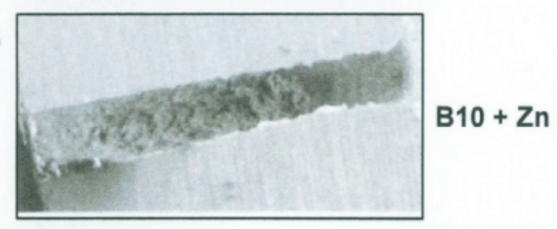

c)

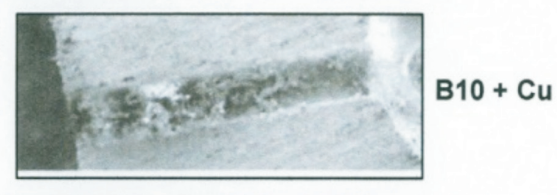

d)

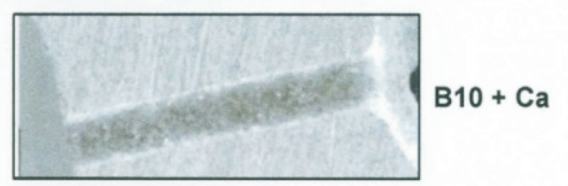

e)

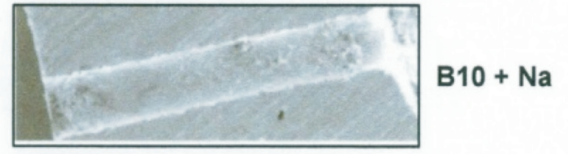

f)

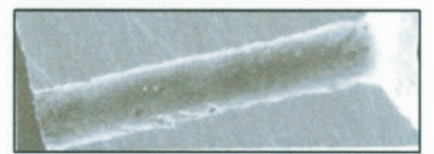

$\mathrm{B} 10+\mathrm{Mg}$

Fig. 5. Catalytic influence of different metal ions on the formation of deposits inside the fuel channels of the HPCR injectors

Rys. 5. Wpływ katalitycznego oddziaływania różnych pierwiastków metalicznych na tworzenie osadów wewnatrz kanalików wtryskiwaczy układu HPCR [12] i powstawania osadów przez rozkład węglowodorów, natomiast termiczny rozkład paliwa powoduje powstawanie osadów węglowych przez polimeryzację. Czynnikiem pogłębiającym te procesy mogą być biokomponenty zawarte $\mathrm{w}$ paliwie, nawet $\mathrm{w}$ małej ilości. Ponadto istotne znaczenie w powstawaniu osadów przypisuje się też polarności związków tworzących prekursory osadów i interakcjom pomiędzy nimi a powierzchnią metali, na której się osadzają [2, 4, 6, 12]. Jednak bardziej prawdopodobny, a w każdym razie także możliwy, wydaje się mechanizm, który zakłada odkładanie się tlenków pierwiastka metalicznego (np. Zn) w postaci osadów wewnątrz kanalików paliwowych wtryskiwaczy [22, 23]. Te organometaliczne osady stanowią odrębny typ osadów chemicznych, które nie były uznawane za groźne dla funkcjonowania układów wtrysku paliwa przed wprowadzeniem układów wysokociśnieniowych. Na rysunku 5 [12] pokazano wpływ śladowych zawartości różnych metali w paliwie B10 na tworzenie osadów organometalicznych wewnątrz kanalików wtryskiwaczy paliwa układu HPCR. Jak można zauważyć, największe osady w kanalikach wtryskiwacza powsta- 


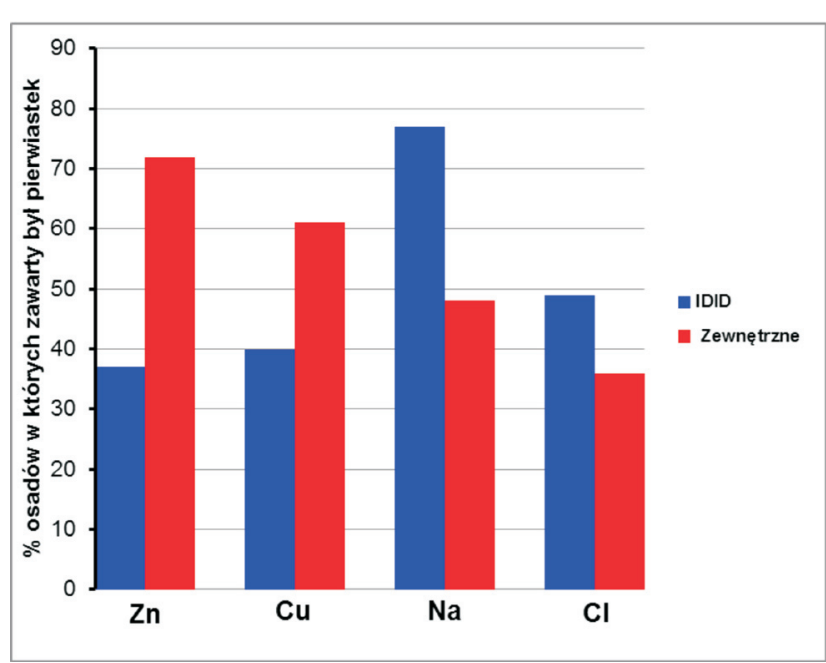

Fig. 6. Comparison of the impact of different metal ions on the formation of external and internal injector deposits

Rys. 6. Porównanie wplywu różnych pierwiastków metalicznych na tworzenie zewnętrznych i wewnętrznych osadów wtryskiwaczy [22]

the biggest threat for the injection systems in the following order: $\mathrm{Cu}>\mathrm{Zn} \sim \mathrm{Na}>\mathrm{Ca}>\mathrm{K}>\mathrm{Mg}[12]$. The influence of different metallic elements possibly contained in the fuel on the formation of both internal and external deposits has been shown in Fig. 6 .

As results from the analysis of figure 6 elements like sodium and chlorine are more impactful on the formation of IDID (Internal Diesel Injector Deposit), while zinc and copper have a greater role in the formation of external deposits, particularly metalorganic ones inside the fuel channels of the injectors [23].

The aim of the authors' own research, performed according to the CEC F-98-08 procedure on a chassis dynamometer with a PSA DW10 diesel engine fitted with HPCR fuel systems, was a comparative assessment of two fuels in terms of their tendency to contaminate fuel injectors. The test of each fuel was carried out twice to confirm the repeatability of the results and the sensitivity of the test stand to distinguishing fuels of different contamination tendency. The tendencies were associated with the possibility of contaminating fuels with traces of metallic elements that could be the catalysts accelerating the formation of deposits in the form of metallic oxides in the injector fuel channels. The influence of other deposits on the injector operational properties was also assessed after the test.

\section{Investigations of the influence of metallic elements in the fuel on the injector deposit formation}

\subsection{Materials used in the research}

The tests were carried out on a CEC DF-79-07/7 diesel fuel recommended by CEC (Coordinating European Council for Development of Performance Tests for Transportation Fuels Lubricants and Other Fluids) as reference and for validation of the test stand with the PSA DW10 engine. The test stand is used for the assessment of the detergent ły na skutek katalitycznego działania $\mathrm{Zn}$ oraz $\mathrm{Cu}$ zawartych w paliwie B10.

Podobne oceny dotyczące katalitycznego wpływu śladowych ilości niektórych pierwiastków metalicznych na procesy starzenia olejów napędowych zawierających 10\% $(V / V)$ FAME i tworzenie osadów w kanalikach wtryskiwaczy układów HPCR przeprowadził Iida [12]. W ich wyniku pierwiastki metaliczne zanieczyszczające przedmiotowe paliwa i stanowiące największe zagrożenia dla układów wtrysku paliwa ze względu na formowanie osadów zewnętrznych zostały uszeregowane w sposób następujący: $\mathrm{Cu}>\mathrm{Zn} \sim \mathrm{Na}$ $>\mathrm{Ca}>\mathrm{K}>\mathrm{Mg}$ [12]. Wpływ różnych pierwiastków metalicznych, mogących stanowić śladowe zanieczyszczenia oleju napędowego, na tworzenie zarówno osadów zewnętrznych, jak i wewnętrznych wtryskiwaczy paliwa przedstawiono na rys. 6 .

Jak wynika z analizy rysunku, pierwiastki takie jak: sód oraz chlor mają większy wpływ na tworzenie osadów wewnętrznych (IDID - Internal Diesel Injector Deposit), natomiast cynk i miedź w większym stopniu przyczyniają się do tworzenia osadów zewnętrznych, zwłaszcza metaloorganicznych wewnątrz kanalików paliwowych wtryskiwaczy [23].

Celem badań własnych, przeprowadzonych wg procedury CEC F-98-08, na stanowisku hamownianym z silnikiem ZS typu PSA DW10 wyposażonym w układ wtrysku paliwa typu HPCR, była ocena porównawcza dwóch paliw pod względem ich tendencji do zanieczyszczania wtryskiwaczy paliwa. Test każdego paliwa był wykonany dwukrotnie w celu potwierdzenia powtarzalności uzyskiwanych wyników oraz czułości stanowiska badawczego w zakresie rozróżniania paliw o różnych tendencjach zanieczyszczania wtryskiwaczy paliwa. Tendencje te wiązano z możliwością zanieczyszczenia paliw śladowymi ilościami pierwiastków metalicznych, mogących stanowić katalizatory przyspieszające tworzenie osadów lub mogących tworzyć osady w postaci tlenków metalicznych, osadzających się w kanalikach paliwowych wtryskiwaczy. Ponadto oceniono też wpływ powstałych osadów na właściwości użytkowo-eksploatacyjne wtryskiwaczy po teście.

\section{Badania wpływu pierwiastków metalicznych w paliwie na tworzenie osadów wtryskiwaczy paliwa}

\subsection{Materiały stosowane $w$ badaniach}

Badaniom poddano paliwo (olej napędowy) CEC DF-7907/7 zalecane przez CEC (Coordinating European Council for Development of Performance Tests for Transportation Fuels Lubricants and Other Fluids) do wzorcowania i sprawdzania stanowiska badawczego z silnikiem PSA DW10, stosowanego do oceny właściwości detergentowych paliw, zgodnie z ogólnoeuropejską procedurą badawczą CEC F-9808 - Injector Fouling in Direct Injection Diesel Engines (DW10). Właściwości fizyko-chemiczne powyższego paliwa przedstawiono w tab. 1. Drugie paliwo, które oceniano w testach powstało po wprowadzeniu $1 \mathrm{mg} / \mathrm{kg}$ Zn do paliwa CEC DF-79-07/7. W ten sposób zwiększono tendencję przed- 
properties of fuels, as per the general European procedure of CEC F-98-08 - Injector Fouling in Direct Injection Diesel Engines (DW10). The physicochemical properties of the said fuel have been presented in table 1. Another fuel that was used in the tests was modified with $1 \mathrm{mg} / \mathrm{kg} \mathrm{Zn}$ (CEC DF79-07/7), which is how the fuel tendency to form external injector deposits was increased. The procedure of introducing Zinc to the fuel was carried out as per recommendations provided in CEC F-98-08 and included purchasing of a Zinc salt, specifically manufactured for the CEC SG-F-098 Work Group (2.2-Zinc dimethyl octanoate), from a recommended supplier, dissolving it in an organic solvent and mixing with a 5 liter volume of the fuel in order to obtain a pre-mixture. The pre-mixture was then mixed with the entire volume of the test fuel. Upon mixing of the fuel and a 4-hour stabilization, a sample was taken to confirm the required density of Zinc in the fuel $(1 \pm 0.1 \mathrm{mg} / \mathrm{kg})$ using the ASTM D 7111 method. The Zinc content in the fuel was also checked at the end of the engine tests.

\subsection{Methodology}

A gradual evolution of diesel engine design, starting from indirect injected engines and low pressure injection systems fitted with rotary injection pumps and pintle injectors has led to the development of HSDI (High Speed Direct Injection) diesel engines with HPCR systems. A significant increase in the fuel injection pressure, injector operating temperatures and the aggressive chemical environment of the combustion chamber in combination with a significant reduction of the outlet hole diameters in the injectors resulted in growing threats of proper operation of injection systems (the entire engine) following the formation of deposits. This forced the engineers to develop a new engine test and a new test procedure to evaluate engine lubricants in terms of their tendency to facilitate formation of deposits in a HSDI miotowego paliwa do tworzenia zewnętrznych osadów wtryskiwaczy paliwa. Procedura wprowadzania cynku do paliwa została przeprowadzona zgodnie z zaleceniami podanymi w CEC F-98-08 i obejmowała zakup, od wskazanego producenta, specjalnej, wytwarzanej na rzecz Grupy Roboczej CEC SG-F-098 soli cynku (2,2-dimetylooktanian cynku), która następnie była rozpuszczana $\mathrm{w}$ rozpuszczalniku organicznym i wprowadzana do 5-litrowej objętości badanego paliwa dla uzyskania tzw. przedmieszki. Przedmieszka natomiast była wprowadzana i mieszana z całą objętością badanego paliwa. Po zakończeniu mieszania paliwa i jego 4-godzinnej stabilizacji pobierana była próbka dla potwierdzenia, czy stężenie zawartego w przygotowanym paliwie cynku mieści się w wymaganych granicach $1 \pm 0,1 \mathrm{mg} / \mathrm{kg}$, przy zastosowaniu metody ASTM D 7111. Zawartość cynku w paliwie była też sprawdzana po zakończeniu testów silnikowych.

\subsection{Metodyka badań}

Stopniowa ewolucja konstrukcji silników ZS, począwszy od silników z wtryskiem pośrednim i niskociśnieniowymi układami wtrysku paliwa wyposażonymi w rozdzielaczowe (rotacyjne) pompy paliwa i wtryskiwacze czopikowe, doprowadziła do wprowadzenia silników ZS typu HSDI (High Speed Direct Injection) z wysokociśnieniowymi układami wtrysku paliwa typy HPCR. Znaczne podwyższenie ciśnienia wtrysku paliwa, temperatur pracy wtryskiwaczy i oddziaływanie na nie agresywnego środowiska chemicznego, bezpośrednio w komorze spalania, w połączeniu ze znacznym ograniczeniem średnicy otworków wylotowych paliwa we wtryskiwaczach spowodowało coraz większe zagrożenia tworzonych osadów dla poprawnego funkcjonowanie układów wtrysku paliwa, a w związku z tym samego silnika. Wymusiło to konieczność opracowania nowego testu silnikowego, a zarazem procedury badawczej, do oceny olejów napędowych pod kątem ich tendencji do tworzenia przedmiotowych osadów w silnikach

Table 1. Physicochemical properties of the CEC DF-79-07/7 fuel

Tabela 1. Właściwości fizykochemiczne paliwa CEC DF-79-07/7

\begin{tabular}{|c|c|c|c|}
\hline Parameter/parametr & Testing method/metoda badania & Unit/jednostka & Result/wynik oznaczenia \\
\hline Cetane number/liczba cetanowa & PN-EN ISO 5165 & - & 53.1 \\
\hline Density/gęstość at $15^{\circ} \mathrm{C}$ & PN-EN ISO 3675 & $\mathrm{~kg} / \mathrm{m} 3$ & 834.3 \\
\hline Ignition temperature/temperatura zapłonu & PN-EN ISO 2719 & ${ }^{\circ} \mathrm{C}$ & 91 \\
\hline $\begin{array}{l}\text { Blockage temperature of cold CFPP filter/temp. zablokowania } \\
\text { zimnego filtra CFPP }\end{array}$ & PN-EN 116 & ${ }^{\circ} \mathrm{C}$ & -20 \\
\hline Kinematic viscosity/lepkość kinematyczna at $40^{\circ} \mathrm{C}$ & PN-EN ISO 3104 & $\mathrm{~mm} 2 / \mathrm{s}$ & 2.934 \\
\hline Total aromates content/całkowita zawartość aromatów & IP 319 & $\%(\mathrm{~m} / \mathrm{m})$ & 21.1 \\
\hline Sulfur content/zawartość siarki & PN-EN ISO 20846 & $\mathrm{mg} / \mathrm{kg}$ & $<1.0$ \\
\hline $\begin{array}{l}\text { Test of corrosive action on copper/badanie dziatania koroduja- } \\
\text { cego na miedź }\left(3 \mathrm{~h} \text { at } 50{ }^{\circ} \mathrm{C}\right)\end{array}$ & PN-EN ISO 2160 & - & $1 \mathrm{a}$ \\
\hline $\begin{array}{l}\text { Remains after coking in } 10 \% \text { distillation residue/pozostałość } \\
\text { po koksowaniu w } 10 \% \text { pozostałości destylacyjnej }\end{array}$ & PN-EN ISO 10370 & $\%(\mathrm{~m} / \mathrm{m})$ & $<0.10$ \\
\hline Residue after reduction to ash/pozostałość po spopieleniu & PN-EN ISO 6245 & $\%(\mathrm{~m} / \mathrm{m})$ & $<0.001$ \\
\hline Water content/zawartość wody & PN-EN ISO 12937 & $\%(\mathrm{~m} / \mathrm{m})$ & 0.004 \\
\hline Resistance to oxidation/odporność na utlenianie & PN-ISO 12205 & $\mathrm{mg} / \mathrm{ml}$ & 0.002 \\
\hline $\begin{array}{l}\text { Greasiness, adjusted diameter of the trace of wear/smarność, } \\
\text { skorygowana średnica śladu zużycia (WS1,4) }\end{array}$ & PN-EN ISO 12156-1 & $\mu \mathrm{m}$ & 302 \\
\hline Calorific value/wartość opałowa & ASTM D 3338 & $\mathrm{MJ} / \mathrm{kg}$ & 43.203 \\
\hline
\end{tabular}


engines fitted with HPCR systems. The procedure was to replace the first general European test procedure (with and without oil additives) developed within the CEC in 1995 for evaluation of the oil tendency to coke injector nozzles. The replaced procedure was referred to as CEC F-23-01. As a test tool, PSA XUD9 A/L indirect injected diesel engine was used fitted with rotary injection pump and pintle injectors. In March 2008 a new test procedure developed within CEC referred to as CEC F-98-08 was introduced. The test engine was PSA DW10, whose selected technical parameters have been presented in table 2 .

The test conducted according to the CEC F-98-08 procedure aims at distinguishing and evaluating diesel fuels in terms of their tendency to facilitate the formation of external deposits on the injectors. The criterion in the test was the decrease of the power output (given in percent) resulting from the distortions in qualitative and quantitative fuel dosage by the contaminated injectors. A positive outcome of the fuel test assumes that it does not result in a decrease of power output greater than $2 \%$. To intensify the process of deposition on the injector nozzles the fuel is enriched with $1 \mathrm{mg} / \mathrm{kg}$ of $\mathrm{Zn}$ that is a catalyst significantly accelerating the deposit formation and forming metalorganic deposits in the form of zinc oxides. Initially, 10\% FAME additives (as more representative deposition facilitator for modern fuels) were applied instead of $\mathrm{Zn}$, yet, due to much worse repeatability and reproducibility of the results the authors eventually returned to the application of $\mathrm{Zn}$.

From the formal point of view, the CEC F-98-08 procedure is designed to evaluate the 'keep clean' efficiency of the fuel in tests conducted for $44 \mathrm{~h}$. It is however possible to conduct extended two-stage 'dirty up - clean up' tests in procedures realized according to arrangements made with clients. Figure 7 presents the INiG test stand for the assessment of the injector contamination in the PSADW10 engine according to the CEC F-98-08 procedure.

typu HSDI z układami wtrysku paliwa HPCR. Procedura ta miała zastępować, opracowaną w ramach CEC w 1995 r., pierwszą ogólnoeuropejską procedurę do oceny olejów napędowych bez pakietu i z pakietem dodatków uszlachetniających, pod kątem ich skłonności do zakoksowania rozpylaczy wtryskiwaczy, oznaczoną jako CEC F-23-01. Jako narzędzie do badań stosowano tam silnik Diesla PSA XUD9 A/L $\mathrm{z}$ pośrednim wtryskiem paliwa wyposażony w układ wtryskowy z rotacyjną pompą paliwa i wtryskiwacze czopikowe. W marcu 2008 r. zatwierdzono i wprowadzono do stosowania opracowaną w ramach CEC nową procedurę badawczą, oznaczoną CEC F-98-08. Jako silnik badawczy zastosowano jednostkę napędową PSA DW10, której wybrane parametry techniczne podano w tab. 2.

Test prowadzony wg procedury CEC F-98-08 ma na celu rozróżnianie i ocenę olejów napędowych pod względem ich tendencji do tworzenia osadów zewnętrznych wtryskiwaczy paliwa. Jako kryterium oceny testu przyjęto wielkość spadku mocy maksymalnej silnika, podawaną w procentach, spowodowaną zaburzeniami w ilościowym i jakościowym dozowaniu paliwa przez zanieczyszczone podczas testu wtryskiwacze. Pozytywna ocena paliwa zakłada, że nie powinno ono powodować większego spadku mocy niż max. 2\%. Dla zintensyfikowania procesu odkładania się osadów na końcówkach wtryskiwaczy wprowadza się do badanego paliwa $1 \mathrm{mg} / \mathrm{kg}$ Zn stanowiącego katalizator znacznie przyspieszający formowanie osadów i tworzący metaloorganiczne osady w postaci tlenków cynku. Początkowo zamiast Zn próbowano stosować dodatek 10\% FAME jako bardziej reprezentatywnego, dla współczesnych paliw, czynnika wspomagającego tworzenie osadów wtryskiwaczy, ale z uwagi na znacznie gorszą powtarzalność i odtwarzalność uzyskiwanych wyników, ostatecznie pozostano przy stosowaniu $\mathrm{Zn}$.

Z formalnego punktu widzenia procedura CEC F-9808 przeznaczona jest do oceny utrzymywania czystości wtryskiwaczy (keep clean) przez oceniane paliwo

Table 2. Selected parameters of the PSA DW10 engine Tabela 2 Wybrane parametry techniczne silnika PSA DW10

\begin{tabular}{|l|c|}
\hline Engine design parameters/konstrukcja & $\begin{array}{c}\text { Four-stroke turbocharged, diesel engine fitted } \\
\text { with EGR/silnik 4-suwowy, z zaptonem } \\
\text { samoczynnym, turbodoładowany z EGR }\end{array}$ \\
\hline Type of fuel injection/typ wtrysku paliwa & $\begin{array}{c}\text { HPCR direct injection with 6-hole injectors } \\
\text { Euro 5); Maximum injection pressure: 1600 bar/ } \\
\text { bezpośredni wtrysk paliwa typu HPCR z 6-o- } \\
\text { tworkowymi wtryskiwaczami Euro 5 maksymalne } \\
\text { ciśnienie wtrysku: 1600 bar }\end{array}$ \\
\hline Arrangement of cylinders/uktad cylindrów & Straight, vertical/rzędowy, pionowy \\
\hline Number of cylinders/liczba cylindrów & 4 \\
\hline Injection order/kolejność wtrysku paliwa & $1-3-4-2$ \\
\hline Timing system/typ uktadu rozrząu & DOHC/4 VPC \\
\hline Displacement/pojemność skokowa & $1998 \mathrm{~cm}^{3}$ \\
\hline Maximum power output/moc maksymalna & Euro IV (with DPF) \\
\hline Maximum torque/maks. moment obrotowy & $100 \mathrm{~kW} @ /$ przy 4000 rpm \\
\hline $\begin{array}{l}\text { Exhaust emissions standard/spełniana norma } \\
\text { zakresie wielkości emisji składników szko- } \\
\text { dliwych do atmosfery }\end{array}$ & $320 \mathrm{Nm} \mathrm{@/przy} \mathrm{2000} \mathrm{rpm}$ \\
\hline
\end{tabular}

w teście prowadzonym przez $44 \mathrm{~h}$. Jednak możliwe jest również prowadzenie wydłużonych, dwuetapowych ocen typu ,dirty up - clean up" w testach wykonywanych wg uzgodnień z klientami. Na rysunku 7 przedstawiono stanowisko INiG do oceny zanieczyszczenia wtryskiwaczy silnika PSA DW10 wg procedury CEC F-98-08.

Temperatura, do której nagrzewają się końcówki wtryskiwaczy jest jednym z najważniejszych kryteriów decydujących o szybkości i wielkości powstawania na nich osadów, dlatego stanowiła ona podstawę przy opracowywaniu 12-fazowego, powtarzanego cyklu badawczego, składającego się na test. Prowadzone badania potwierdziły, że wzrost temperatury końcówek wtryskiwaczy koreluje $\mathrm{z}$ intensywnością tworzonych 


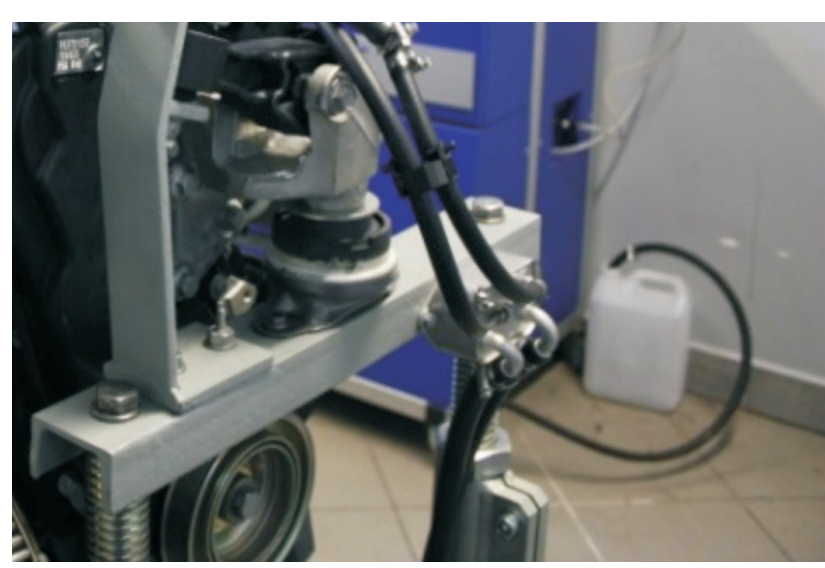

Fig. 7. Dynamometer test bed with the PSA DW10 engine for the evaluation of fuel injector contamination according to the CEC F-98-08 test procedure

Rys. 7. Stanowisko badawcze z silnikiem PSA DW10 do oceny zanieczyszczenia wtryskiwaczy paliwa wg procedury CEC F-98-08

The temperature that the injection nozzles reach is one of the most important criterions decisive of the rate and size of the deposit formation, which is why it was the basis for the development of the 12-stage repeatable test cycle constituting the test procedure. The performed research has confirmed that the increase in the injector nozzle temperature correlates with the intensity of deposit formation and the changes in the engine power output [21]. As a result, in the developed test cycle, the adopted maximum loads of the PSA DW10 engine resulted in the heating of the injector nozzles to the temperature of $230^{\circ} \mathrm{C}$ to $240^{\circ} \mathrm{C}$. This as well as the catalytic influence of $\mathrm{Zn}$ led to the reduction of time needed for the formation of deposits to $44 \mathrm{~h}$.

\subsection{Results}

Figure 8 presents changes in the power output of the PSA DW10 engine given in percent during the performance of four tests within the research project. As per the assumptions, in first two tests the CEC DF-79-07/7 fuel without metallic elements was evaluated and in the subsequent two, the assessment was performed on the same fuel containing $1 \mathrm{mg} / \mathrm{kg} \mathrm{Zn}$.

When evaluating the obtained test results, the authors took into consideration the average ranges of evaluations in which the changes in the maximum power outputs of the PSA DW10 engine could fall as determined by CEC for the CEC DF-79-07/7 reference fuel containing $1 \mathrm{mg} / \mathrm{kg} \mathrm{Zn}$ and without it in the test conducted according to the CEC F-9808 specifications. According to the $\mathrm{CEC}$ requirements, the assessment of the CEC DF-79-07/7 reference fuel not containing $\mathrm{Zn}$ should be $0 \pm 0.99 \%$ of the change in the maximum power output and for the CEC DF-79-07/7 fuel containing $\mathrm{Zn}--5.5 \pm 1.5 \%$ of the change in the maximum power output. The results of the evaluations of the CEC DF-79-07/7 reference fuel not containing Zinc obtained in the research in two consecutive engine tests were: $-0.2 \%$ and $-0.05 \%$ respectively (Fig. 8) of the maximum decrease of the power output, hence they fitted well in the range from $-0.99 \%$ to $0.99 \%$ of the changes in the maximum power output set as na nich osadów i zmianami mocy silnika [21]. W rezultacie w opracowanym cyklu badawczym przyjęte maksymalne obciążenia silnika PSA DW10 powodują nagrzewanie się końcówek wtryskiwaczy do temperatury rzędu od $230{ }^{\circ} \mathrm{C}$ do $240{ }^{\circ} \mathrm{C}$. To wraz z katalitycznym oddziaływaniem $\mathrm{Zn}$ na tworzone osady pozwoliło skrócić jego czas do $44 \mathrm{~h}$.

\subsection{Wyniki badań}

Na rysunku 8 przedstawiono procentowe zmiany mocy maksymalnej silnika PSA DW10 podczas prowadzenia czterech testów wykonanych w ramach projektu badawczego. Zgodnie z założeniami, w dwóch testach oceniono paliwo CEC DF-79-07/7 bez pierwiastków metalicznych, a w kolejnych dwóch to samo paliwo jednak zawierające $1 \mathrm{mg} / \mathrm{kg} \mathrm{Zn}$.

Przystępując do oceny uzyskanych wyników badań silnikowych, wzięto pod uwagę wyznaczone przez CEC, dla paliwa wzorcowego CEC DF-79-07/7 bez zawartości i z zawartością $1 \mathrm{mg} / \mathrm{kg} \mathrm{Zn}$, średnie oceny wraz z określonymi granicami, pomiędzy którymi powinny mieścić się wielkości zmian mocy maksymalnej silnika PSA DW10 w teście prowadzonym wg CEC F-98-08. Zgodnie z wymaganiami CEC, ocena paliwa wzorcowego CEC DF-79-07/7 niezawierającego $\mathrm{Zn}$ powinna wynosić $0 \pm 0,99 \%$ zmiany wielkości mocy maksymalnej po teście, a dla paliwa CEC DF-79-07/7 zawierającego Zn - -5,5 $\pm 1,5 \%$ zmiany wielkości mocy maksymalnej po teście. Uzyskane w ramach projektu wyniki ocen paliwa wzorcowego CEC DF-79-07/7 niezawierającego cynku, w dwóch kolejnych testach silnikowych wyniosły odpowiednio: $-0,2 \% \mathrm{i}-0,05 \%$ (rys. 8) utraty mocy maksymalnej silnika po przeprowadzonych testach, a zatem mieszczą się one swobodnie w przedziale od $-0,99 \%$ do 0,99\% zmian wielkości mocy maksymalnej ustalonej jako wymagania dla tego paliwa. Dla testów silnikowych przeprowadzonych z zastosowaniem paliwa CEC DF-79-07/7 z zawartością $1 \mathrm{mg} / \mathrm{kg}$ Zn, uzyskano kolejno wyniki: $-6,05 \%$ i $-5,97 \%$ (rys. 8) zmniejszenia mocy maksymalnej silnika. Wyniki te również mieszczą się swobodnie w granicach od $-7,0 \%$ do $-4,0 \%$ ustalonych jako wymagane dla tego typu paliwa.

Po przeprowadzeniu badań wyżej opisanych paliw w czterech testach silnikowych, postanowiono przeprowadzić głębsze, niezwiązane już z wymaganiami procedury badawczej CEC F-98-08, oceny zanieczyszczenia wtryskiwaczy silnika i ich skutków, w przypadku badania paliwa CEC DF-79-07/7 z zawartością 1 mg/kg Zn. Pierwsza ocena polegała na zrobieniu zdjęć końcówek wtryskiwaczy i optycznej ocenie osadów zewnętrznych zgromadzonych na ich końcówkach po teście wyżej wymienionego paliwa - rys. 9.

Rysunek 9 wskazuje, że w wyniku przeprowadzonego testu nie powstały duże osady koksowe na końcówkach ani wokół otworków wylotowych paliwa wtryskiwaczy, pomimo znacznego spadku mocy maksymalnej silnika. W związku z tym postanowiono sprawdzić parametry diagnostyczne i użytkowe dwóch spośród czterech wtryskiwaczy po teście. Dodatkowo, dla celów porównawczych, ocenie poddano też wtryskiwacz zupełnie nowy. Testy prowadzone były na 


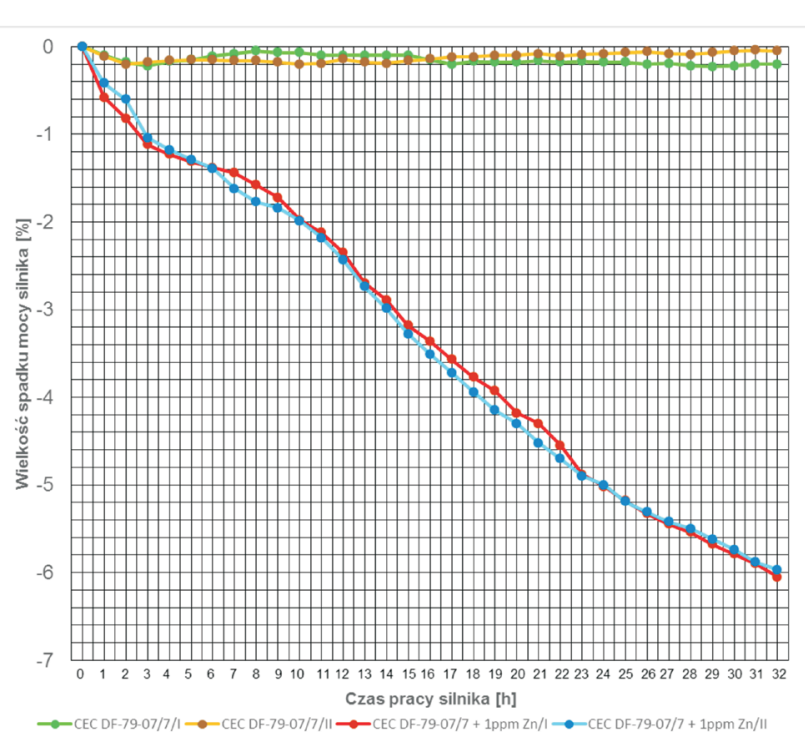

Fig. 8. Comparison of the changes in the power output of the PSA DW10 engine for fuels with and without $1 \mathrm{mg} / \mathrm{kg} \mathrm{Zn}$

Rys. 8. Zmiany wielkości mocy maksymalnej silnika PSA DW10 podczas testów paliwa bez zawartości i z zawartością $1 \mathrm{mg} / \mathrm{kg} \mathrm{Zn}$

required for this fuel. For the engine tests performed with the CEC DF-79-07/7 fuel containing $1 \mathrm{mg} / \mathrm{kg} \mathrm{Zn}$, the following results were obtained: $-6.05 \%$ and $-5.97 \%$ (Fig. 8) of the decrease of the engine maximum power output. These results also fitted well in the range from $-7.0 \%$ to $-4.0 \%$ set as required for this type of fuel.

After the investigations of the discussed fuels in four engine tests, the authors decided to carry out more detailed (not subject to the requirements of the CEC F-98-08 test procedure) evaluations of the injector contamination and its consequences for the CEC DF-79-07/7 fuel containing $1 \mathrm{mg} /$ $\mathrm{kg} \mathrm{Zn}$. The first evaluation consisted in taking photographic images of the injection nozzles and optical assessment of the external deposits built on the nozzles after the test with the discussed fuel- Fig. 9.

Figure 9 shows that, following the performed test, no significant coking deposits formed around the outlet holes and on the injector nozzles, despite a significant decrease of the maximum power output. The authors decided to check the diagnostic and operational parameters of two out of four injectors after the test. Additionally, for comparison, a brand new injector was subjected to evaluation. The tests were carried out on Zapp CRU.21 diagnostic device used for the measurement of usable parameters of the Continental injectors applied, inter alia, in the tested DW10 engines. The test of each of the injectors consisted in measuring several different parameters, and evaluating them in terms of the admissible/inadmissible deviations specified in the injector manufacturer requirements. Figure 10 shows the evaluations of four selected parameters of the tested injectors. Each evaluation was additionally presented in a graphical form on a short fragment in time of a given parameter of the tested injector referred to the admissible (dashed lines) and inadmissible (continuous lines) deviations. Besides, the courses of the parameters of fully operative injectors urządzeniu diagnostycznym „Zapp CRU.21” służącym do pomiaru i oceny parametrów użytkowych wtryskiwaczy Continental, stosowanych, między innymi, w silnikach testowych DW10. Test każdego wtryskiwacza polegał na pomiarze kilkunastu różnych parametrów, a następnie przeprowadzeniu ich oceny w odniesieniu do dopuszczalnych i niedopuszczalnych odchyłek określonych przez normy producenta wtryskiwaczy. Na rysunku 10 podano zestawienie ocen czterech wybranych parametrów testowanych wtryskiwaczy. Każda ocena jest dodatkowo przedstawiona graficznie na małym przebiegu określonego parametru testowanego wtryskiwacza odniesionego do dopuszczalnych odchyłek (linie przerywane) i niedopuszczalnych odchyłek (linie ciągłe). Ponadto przebiegi parametrów w pełni sprawnych wtryskiwaczy zobrazowano kolorem niebieskim, przebiegi parametrów wtryskiwaczy wykraczające poza granice ostrzegawcze (odchyłki dopuszczalne), a zatem niewykluczające ich z dalszej eksploatacji i nie wymagające naprawy, ale wskazujące na ich odstępstwa od parametrów optymalnych, przedstawiono w kolorze zielonym, natomiast przebiegi żółte obrazują parametry wtryskiwaczy, które nie mieszczą się w granicach tolerancji dopuszczalnych przez producenta. Takie wtryskiwacze muszą podlegać czyszczeniu i/lub naprawie, a następnie ponownej regulacji. Dodatkowo wynik testu wtryskiwacza, który w zakresie badanego parametru wykazał odchyłki niemieszczące się w granicach tolerancji określonej przez producenta wtryskiwacza, oznaczono czerwonym wykrzyknikiem. Na rysunku 10 podano zestawienie wybranych, ocenianych parametrów trzech wtryskiwaczy, w tym jednego nowego i dwóch po teście na stanowisku z silnikiem PSA DW10 zasilanym paliwem CEC DF-79-07/7 z zawartością $1 \mathrm{mg} / \mathrm{kg}$ Zn. Jak można zauważyc, dla jednego z wtryskiwaczy po teście, dwa parametry wykazały niedopuszczalne odchyłki od normy, a dla drugiego - jeden. Rozpatrując prawdopodobne przyczyny takich odstępstw, należy wskazać na osady powstałe w kanalikach otworków wylotowych paliwa, które mogły być przyczyną zmniejszenia dawek wtryskiwanego paliwa przy różnych ciśnieniach i czasach wysterowania. Z kolei przyczyn rosnącego opóźnienia otwarcia wtryskiwacza względem momentu podania sygnału wysterowującego oraz podwyższenia ciśnienia otwarcia wtryskiwacza należy poszukiwać w wytworzeniu się wewnętrznych osadów we wtryskiwaczu. Osady takie mają wpływ na opory ruchu, a zatem i dynamikę pracy iglicy, sterującej zarówno chwilą, jak i czasem otwarcia wtryskiwacza.

\section{Podsumowanie}

Przeprowadzone badania potwierdziły, że nawet śladowe ilości (rzędu $1 \mathrm{mg} / \mathrm{kg}$ ) niektórych pierwiastków metalicznych zawartych jako zanieczyszczenia w oleju napędowym stanowią duże zagrożenie dla poprawnego funkcjonowania nowoczesnych układów wtrysku paliwa typu HPCR. Ich katalityczne działanie przyspiesza procesy utleniania oraz degradacji paliwa i skutkuje formowaniem się szkodliwych osadów węglowych w obszarze otworków wylotowych wtryskiwaczy paliwa. Równocześnie pierwiastki metaliczne mogą tworzyć tlenki metali odkładające się na powierzchni 
were marked with blue color. The courses of injector parameters out of typical range (still admissible, good for further operation, not requiring repair but showing certain deviations) were marked with green color and the yellow color marked the injector parameters that fell outside the admissible range recommended by the manufacturer. Such injectors must undergo a cleaning procedure, a repair and then readjustment. Additionally, the results of the injector test exhibiting deviations from the tolerance range as specified by the manufacturer were marked with a red exclamation mark. Figure 10 shows selected evaluated parameters of three injectors including one brand new and two after the tests performed on the test bed with the PSA DW10 engine fueled with the CEC DF-79-07/7 fuel containing $1 \mathrm{mg} / \mathrm{kg}$ $\mathrm{Zn}$. As we can observe, for one of the injectors after the test, two parameters were inadmissibly deviated from the standard and for the other injector one parameter was out of the admissible range. Analyzing the probable reasons for these deviations one should point to the deposits formed in the fuel channels of the injector outlet holes that may have limited the fuel dosage at different pressures and injection timings. The reason for the increasing delay of the injector opening versus the control signal and increased opening pressure is the formation of internal deposits inside the injector. These deposits are impactful on the motion resistance, hence the dynamics of the needle operation that controls both the moment and duration of injector opening.

\section{Conclusions}

The performed tests have confirmed that even traces of some metallic elements (as little as $1 \mathrm{mg} / \mathrm{kg}$ ) contained in the diesel fuel as contaminants are bad for modern HPCR injection systems. Their catalytic influence accelerates the processes of oxidation and degradation of fuel, which results in the formation of carbon deposits around the outlet hole of the injectors. Metallic elements may also form metal oxides depositing on the surfaces of the fuel channels of the injector (metalorganic deposits). Both deposits have an adverse effect on the quality of the fuel atomization and its mixing with air in the engine combustion chamber, let alone the quantitative changes in the fuel fed to the combustion chamber. This results in uncontrolled change of the excess air coefficient of the air-fuel mixture. The evaluation of the
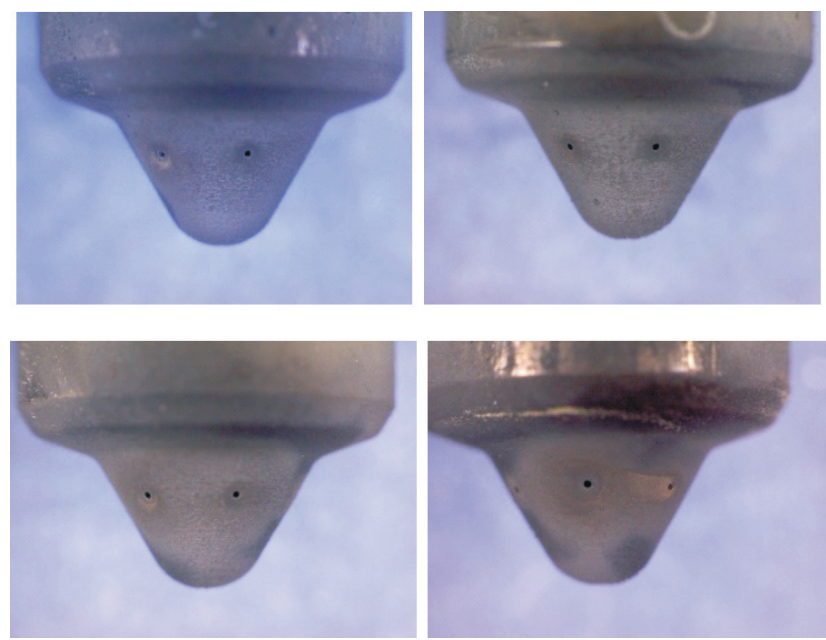

Fig. 9. View of the injector nozzles of the PSA DW10 engine after the test for the CEC DF-79-07/7 reference fuel containing $1 \mathrm{mg} / \mathrm{kg} \mathrm{Zn}$ Rys. 9. Końcówki wtryskiwaczy silnika PSA DW10 po teście paliwa wzorcowego CEC DF-79-07/7 z zawartościa $1 \mathrm{mg} / \mathrm{kg} \mathrm{Zn}$

kanalików paliwowych w postaci osadów organometalicznych. Zarówno jedne osady, jak i drugie wpływają na pogorszenie jakości rozdrobnienia paliwa i jego zmieszania z powietrzem w komorach spalania silnika, oraz zmiany ilości paliwa wtryskiwanego do komór spalania, powodując niekontrolowane zmiany współczynnika nadmiaru powietrza mieszanki palnej. Oceny parametrów użytkowo-eksploatacyjnych wtryskiwaczy paliwa po teście paliw zawierających $1 \mathrm{mg} / \mathrm{kg}$ Zn potwierdziły, że w wielu przypadkach nie spełniają one wymagań producenta, a ich stosowanie powoduje pogorszenie osiągów silnika, utrudniony rozruch, zwiększenie zużycia paliwa oraz emisji szkodliwych składników spalin. Najskuteczniejszym sposobem ograniczania występowa-
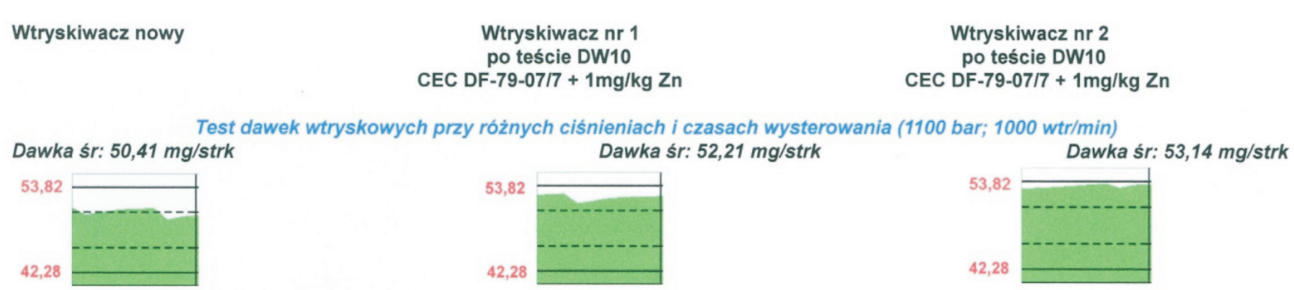

Test dawek wtryskowych przy różnych ciśnieniach i czasach wysterowania (700 bar; 1000 wtr/min)

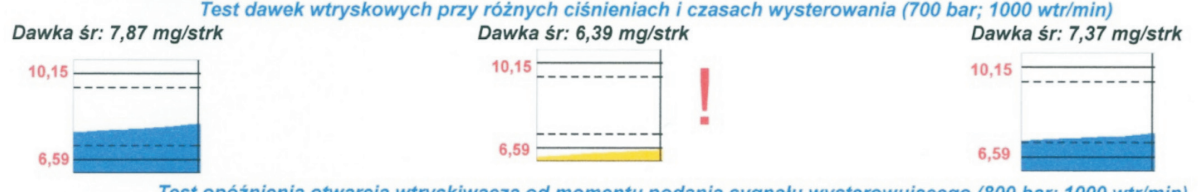

Test opóżnienia otwarcia wtryskiwacza od momentu podania sygnału wysterowującego (800 bar; $1000 \mathrm{wtr} / \mathrm{min}$ )

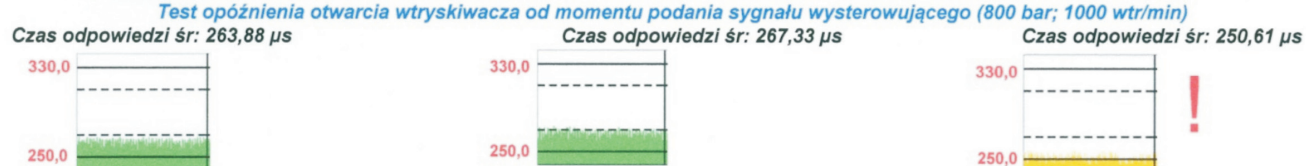

Ciśnienie otwarcia wtryskiwacza mierzone przy jego wysterowaniu ( $800 \mathrm{bar} ; 600 \mathrm{wtr} / \mathrm{min}$ )

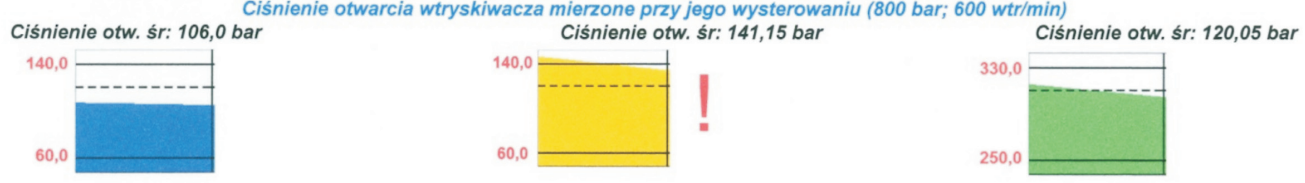

Fig. 10. Results of the assessment of selected diagnostic parameters of the fuel injectors

Rys. 10. Wyniki ocen wybranych parametrów diagnostycznych wtryskiwaczy paliwa 
operating parameters of fuel injectors after the tests carried out on fuels containing $1 \mathrm{mg} / \mathrm{kg} \mathrm{Zn}$ has confirmed that in many cases these fuels do not meet the engine manufacturer requirements and their use results in reduced engine performance, difficult engine start, increased fuel consumption and exhaust emissions. The best method to limit the occurrence of the above phenomena is the application of effective detergent fuel additives. Their composition and influence, however, must be regularly adapted to the ever-changing technologies of fuel production and composition as well as design and operating conditions of rapidly advancing fuel injection system technologies. nia wyżej opisanych, niekorzystnych zjawisk jest stosowanie efektywnych dodatków detergentowych do paliw. Jednak ich skład i działanie muszą być sukcesywnie dostosowywane do zmieniających się technologii produkcji i składu paliw oraz konstrukcji, technologii wykonania i warunków pracy szybko rozwijanych układów wtrysku paliwa.

\section{Bibliography/Literatura}

[1] Stępień Z. Intake valve and combustion chamber deposits formation - the engine and fuel related factors that impacts their growth. Nafta-Gaz, kwiecien 2014, nr 4/2014 s. 28-34. Wydawnictwo Instytutu Nafty i Gazu, ISSN 0867-8871.

[2] Stępien $Z$. The reasons and adverse effect of internal diesel injector deposits formation - Przyczyny powstawania i szkodliwy wpływ wewnętrznych osadów we wtryskiwaczach silników o zapłonie samoczynnym. Combustion Engines. 2014, 156(1), 20-29, ISSN 0138-0346.

[3] Stępień, Z. Deposit in spark ignition engines - formation and threats. Combustion Engines. 2015, 160(1), 36-48, ISSN 2300-9896.

[4] Żak G., Ziemiański L., Stępień Z., Wojtasik M. Problemy związane z tworzeniem się osadów na elementach układów wtryskowych nowoczesnych silników Diesla - przyczyny, metody badań, przeciwdziałanie. Nafta-Gaz, 2013, 9, 702-708. Wydawnictwo Instytutu Nafty i Gazu, ISSN 0867-8871.

[5] Stępień Z., Oleksiak S. Przyszłościowe kierunki rozwoju konstrukcji silników HD Diesel. II Międzynarodowy Kongres Silników Spalinowych, Kraków 20-23 maja 2007, publikacja w mat. Konferencyjnych i Silniki Spalinowe.

[6] Stępień Z., Urzędowska W., Rożniatowski K. Influence of Fuel Quality on Advanced Diesel Injection Systems Failures - referat wygłoszony na Kongresie Międzynarodowym - Engine Combustion Processes- Current Problems and Modern Techniques - Monachium 15-16.03.2007 r.

[7] Stępień Z., Oleksiak S., Dybich K. Rozwój silnikowych metod badawczych „CEC” do oceny właściwości użytkowych paliw. Międzynarodowa Konferencja KONES 2007, 9-11.09.2007 Rynia.

[8] Stępień Z. Obecne i przyszłe silnikowe metody oceny właściwości detergentowych olejów napędowych. KONMOT 2014.

Zbigniew Stępień, DEng. - Assistant Professor, Head of Laboratory of Engine and Tribological Research, Deputy Head of the Chair of Operational Properties Assessment of Oil and Gas Institute at National Research Institute in Krakow.

Dr inż. Zbigniew Stępień - adiunkt, kierownik Laboratorium Badań Silnikowych i Trybologicznych, z-ca kierownika Zakładu Oceny Właściwości Eksploatacyjnych w Instytucie Nafty i Gazu - Państwowym Instytucie Badawczym w Krakowie.

e-mail: stepien@inig.pl
[9] Parsinejad F., Biggs W. Direct Injection Spark Ignition Engine Deposit Analysis: Combustion Chamber and Intake Valve Deposits. SAE Paper 2011-01-2110.

[10] Bennet J. Application and Testing of Fuel Detergents for Direct Injection Gasoline Engines - Fuels - International Colloquium, January 19-20, 2013, Essilngen, Germany.

[11] Hongming Xu, Chongming W., Xiao Ma, Asish K., Well A., Krueger-Venus J. Fuel injector deposits in direct-injection spark-ignition engines - Progress in Energy and Combustion Science. 2015, 50, 63-80.

[12] Iida Y. Biodiesel Studies in Japan - CEN/TC19/WG24, 22 May 2012.

[13] Caprotti R., Bhatti N., Balfour G. Deposit Control in Modern Diesel Fuel Injection Systems - SAE Technical Paper No 2010-01-2250.

[14] Quigeley R., Barbour R., Arters D., Bush J. Understanding the Spectrum of Diesel Injector Deposits - 9th International Colloquium Fuels, TAE Esslingen, January 15-17 2013.

[15] Quigeley R., Barbour R., Panesar A., Arters D. A Review of Fuel and Additive Performance in the New CEC F-98-08 DW10 Injector Fouling Test - Fuels 2009, 7th International Colloquium, TAE Esslingen, 2009.

[16] Barbour R., Arters D., Dietz M., MacDuff M., Panesar A,; Quigley R. Injector Fouling Effect in Modern Direct Injection Diesels - 13th Annual Fuels and Lubes Asia Conference, 2007. Bangkok, Thailand.

[17] Ullmann J., Geduldig M., Stutzenberger H., Caprotti R., Balfour G. Investigation into the Formation and Prevention of Internal Diesel Injector Deposits. SAE Technical Paper 2008-01-0926.

[18] Venkataraman S., Eser S. Characterization of Deposits Formed on Diesel Injectors in Field Test and from Thermal Oxidative Degradation of n-Hexadecane in a Laboratory Reactor. Chemistry Central Journal 2008, 2:25.

[19] Lepperhoff G., Houben M. Mechanism of Deposit Formation in Internal Combustion Engines and Heat Exchangers. SAE Technical Paper 931032.

[20] Caprotti R., Breakspear A., Graupner O., Klaua T. Diesel Injector Deposits Potential on Future Fuelling Systems. SAE Technical Paper 2006-01-3359.

[21] Macduff M., Barbour R., Panesar A., Arters D., Dietz J., Quigley R. Diesel Detergent Additive Responses in Modern High Speed Direct Injection Light Duty Engines. Fuels 2007, 6th International Colloquium, TAE Esslingen, 2007.

[22] Lacey P., Gail S., Kientz J.M., Milanovic N., Gris C. Internal Injector Deposits. SAE Technical Paper 2011-01-1925. $4 / 2015$. 